\title{
Studies on Enterotoxins and Antimicrobial Resistance in Staphylococcus aureus Isolated from Various Sources
}

\author{
Enas Yasser Mohammed, Shaymaa Hassan Abdel-Rhman*, Rasha Barwa, \\ Mohammed Adel El-Sokkary \\ Microbiology and Immunology Department, Faculty of Pharmacy, Mansoura University, Mansoura, Egypt \\ Email: "Enas_Yasser2009@yahoo.com, shaymaahassan@mans.edu.eg, drshaymaahassan@gmail.com, \\ rasha2000@gmail.com, melsokary@yahoo.com
}

Received 29 February 2016; accepted 10 April 2016; published 13 April 2016

Copyright (C) 2016 by authors and Scientific Research Publishing Inc.

This work is licensed under the Creative Commons Attribution International License (CC BY).

http://creativecommons.org/licenses/by/4.0/

(c) (i) Open Access

\section{Abstract}

Staphylococcus aureus represents a public health challenge all over the world. Therefore, this study aims to analyze the prevalence of five genes ( $\mathrm{sea}$, seb, sec, see and seg) encoding the staphylococcal enterotoxins in $S$. aureus isolated from different sources and to evaluate the association of these toxins in comparison to susceptibility towards 12 antimicrobials; antimicrobial susceptibility was conducted by disc diffusion method. Detection of staphylococcal enterotoxins was performed by PCR and the ability to express these genes was assessed among isolates by RT-PCR. The most common enterotoxin gene was sea gene (66\%), followed by seb, sec, see and seg $(38 \%, 23 \%$, $19 \%$ and $5 \%$ ) respectively. Expression of sea, seb and seg genes was variable. However, sec and see genes were not expressed by any of the tested isolates. No statistically significant association exists between (seb, sec and see) and isolation sources, while the sea was significantly associated with clinical isolates. High significant correlation was found between elevated sea expression and multidrug-resistance. Our findings indicate that the pathogenic potential of $S$. aureus may be greater than previously thought. This emphasizes the utmost need to implement proactive measures and more emphasis will be placed on the application of hygiene practices in hospitals to control $S$. aureus infection and enterotoxins production.

\section{Keywords}

S. aureus, Antimicrobial Susceptibility, Enterotoxins, Expression

${ }^{*}$ Corresponding author.

How to cite this paper: Mohammed, E.Y., Abdel-Rhman, S.H., Barwa, R. and El-Sokkary, M.A. (2016) Studies on Enterotoxins and Antimicrobial Resistance in Staphylococcus aureus Isolated from Various Sources. Advances in Microbiology, 6, 263-275. http://dx.doi.org/10.4236/aim.2016.64026 


\section{Introduction}

Staphylococcus aureus (S. aureus) is a major pathogen of increasing importance due to the rise in antibiotic resistance [1]. It is often found as a commensal associated with skin, skin glands, and mucous membranes, mainly in the nose of healthy individuals [2]. Approximately $20 \%-30 \%$ of the general populations are S. aureus carriers [3].

S. aureus is associated with severe community and hospital acquired diseases and has for a long time been considered as a major problem of public health [4]. Many extracellular proteins and toxins are produced which probably contribute to the virulence of this organism [5]. S. aureus can produce exotoxins including exfoliative toxins, leukocidins, toxic shock syndrome toxin-1 (TSST-1) and staphylococcal enterotoxins (SEs) [6]. The spectrum of staphylococcal diseases ranges from pimples and furuncles to toxic shock syndrome and sepsis, most of which depend on many virulence factors. In contrast, some diseases, such as staphylococcal food poisoning, rely on only one type of virulence factors: the staphylococcal enterotoxins (SEs) [4].

Staphylococcal food poisoning (SFP) is a very common, however, a rarely reported, type of food poisoning. Symptoms of SFP include rapid onset (within $1-6 \mathrm{~h}$ ) of nausea, vomiting, diarrhea and abdominal cramps [7]. These symptoms subside within $24-48 \mathrm{~h}$ but the disease may remain for $7-10$ days [8]. The staphylococcal enterotoxins (SEs), produced by S. aureus, are known as etiologic agents of food poisoning in man, and as potent immunologic superantigens [9] that stimulate non-specific T cell proliferation [4]. The staphylococcal enterotoxins are emetic toxins belonging to a large family of staphylococcal and streptococcal pyrogenic exotoxins (PT), having common structure, function phylogenetic relationships and sequence homology [10].

Nowadays, there are 24 types of staphylococcal enterotoxins including staphylococcal enterotoxins (SEs) with demonstrated emetic activity in a primate model (SEA, SEB, SEC, SED, SEE, SEG, SEH, SEI, SEK, SEL, SEM, SEN, SEO, SEP, SEQ, SER, SES and SET) and staphylococcal-like (SEl) proteins, which are not emetic in a primate model or have yet to be tested (SEIJ, SEIU, SEIU2, SEIV, SEIX and SEIY) [11] [12], yet, SEA-SEE are the most common enterotoxins implicated in SFP [13]. SEA and SEB were found to be the most common staphylococcal enterotoxins. SEA is the most implicated toxin in staphylococcal food poisoning (SFP). For SEB, it has also been associated with food poisoning and was studied for the potential risk of being used as an inhaled bioweapon. SED is the second most common staphylococcal toxin associated with SFP in the world, and minute amounts of this toxin were found enough to induce illness. SEC was the most predominant enterotoxin detected in S. aureus strains isolated from mastitis milk in sheep, goats, and cattle. SEE has been reported in few cases of food poisoning [14]. SEG is an example of the non-classical enterotoxins which also show emetic properties [15]. The SEs are resistant to inactivation by gastrointestinal proteases such as pepsin and trypsin and these toxins also show thermal stability [10] making their elimination difficult to achieve [6]. Therefore, detection of SEs in foods is necessary for risk management and surveillance in food safety. Many reports have described the development of molecular methods for the detection of most of the SE genes [16].

For classical staphylococcal enterotoxin detection, the reversed phase latex agglutination (SET-RPLA) and staphylococcal enterotoxin enzyme immuno-assay (SET-EIA) kits, were used to be employed. However, due to the unavailability of immunoassay kits for detecting new SEs, other methods as polymerase chain reaction (PCR) primers, DNA probes and reverse-transcription (RT)-PCR were used for the detection of these toxin genes and their activity in $S$. aureus strains [17].

This study has been undertaken to detect enterotoxin genes in $S$. aureus by PCR, assess their distribution among various clinical and environmental sources and measure their expression levels by RT-PCR. Moreover, as the relationship between resistance and virulence is poorly understood, we tried to find any possible correlation between prevalence and expression of enterotoxins on one hand and antimicrobial susceptibility on the other hand.

\section{Materials and Methods}

\subsection{Study Design}

During the period from June 2013 and January 2014, 250 samples were collected from different hospitals. These isolates were obtained from different clinical and environmental sources. One hundred isolates were identified as $S$. aureus using standard microbiological techniques according to [18]. The experimental protocol conducted in the study was approved by the Ethical Committee of faculty of Pharmacy, Mansoura University, Egypt, with code (2013-28) in May 2013. 


\subsection{Antimicrobial Susceptibility Testing}

The antimicrobial susceptibility testing was carried out by disk diffusion method using Mueller-Hinton agar plates (oxoid) according to [19] where 12 antimicrobial agents belonging to different classes were selected including: ampicillin-sulbactam (SAM, 10/10 $\mu \mathrm{g}$ ), amoxicillin-clavulanic acid (AMC, 20/10 $\mu \mathrm{g}$ ), oxacillin (OX, $1 \mu \mathrm{g}$ ), imipenem (IPM, $10 \mu \mathrm{g}$ ), cephalothin (KF, $30 \mu \mathrm{g}$ ), cefoxitin (FOX, $30 \mu \mathrm{g}$ ), ceftazidime (CAZ, $30 \mu \mathrm{g}$ ), cefepime (FEB, $30 \mu \mathrm{g}$ ), amikacin (AK, $30 \mu \mathrm{g}$ ), tobramycin (TOB, $10 \mu \mathrm{g}$ ), erythromycin (E, $15 \mu \mathrm{g}$ ) and ciprofloxacin (CIP, $5 \mu \mathrm{g})$.

Cefoxitin $(30 \mu \mathrm{g})$ disk was used for detection of methicillin resistant Staphylococcus aureus (MRSA), where strains with Inhibition zone diameter $\leq 21$ were identified as MRSA [19] [20].

\subsection{PCR Detection of Staphylococcal Enterotoxins Genes}

PCR amplification of staphylococcal enterotoxins (SE) genes, namely (sea, seb, sec, see and seg) was performed using a single plex PCR reaction (FPROGO2D, Tchne LTD, Oxford Cambridge, UK) and specific primers listed in Table 1. Genomic DNA was prepared by picking up one - two colonies grown overnight on nutrient agar medium and resuspended in $100 \mu \mathrm{l}$ of nuclease free water then heated to $95^{\circ} \mathrm{C}$ for 10 mins. The toxin genes were detected and amplified using the following reaction: $12.5 \mu$ DreamTaq Green PCR Master Mix (2X) (Thermo scientific), $3 \mu \mathrm{l}$ of bacterial DNA, $1 \mu \mathrm{l}$ of each primer $(10 \mu \mathrm{M})$, and $7.5 \mu \mathrm{l}$ nuclease free water (Thermo scientific) for a total of $25 \mu \mathrm{l}$ per reaction.

The PCR program started with an initial denaturation of DNA at 95C for 5 mins, followed by 35 cycles of denaturation at $95^{\circ} \mathrm{C}$ for $30 \mathrm{~s}$, annealing at temperatures specified for each primer as listed in Table 1 for $30 \mathrm{~s}$ and extension at $72^{\circ} \mathrm{C}$ for $1 \mathrm{~min}$. This was followed by a final extension step at $72^{\circ} \mathrm{C}$ for 5 mins. The amplified genes were visualized on $2 \%$ agarose gel electrophoresis stained with ethidium bromide and compared with a 100 base pair (bp) DNA ladder (Thermo scientific).

\subsection{RNA Isolation}

RNA was isolated from 20 isolates. We selected isolates that harbored 3 or more of the tested toxin genes as detected by PCR (11 isolates), and isolates shared the same resistance and toxin gene pattern (9 isolates). RNA isolation was done according to [22] using glass beads and TRI reagent (Sigma Aldrich).

The concentration and the purity of RNA for each isolate were determined spectrophotometrically using 260 and 260/280 nm ratio respectively, using NanoDrop (ND-1000 Spectrophotometer, NanoDrop Technologies, Wilmington, Delaware, USA). The purity of RNA was determined by calculating the ratio of A260/A280. Pure RNA has a ratio of 1.8:2.1.

Table 1. Specific amplification primer sets of staphylococcal enterotoxin genes and reference gene (nuc).

\begin{tabular}{|c|c|c|c|c|c|}
\hline Gene name & & Sequence & Temp. & $\begin{array}{l}\text { Amplicon } \\
\text { Length (bp) }\end{array}$ & Reference \\
\hline \multirow{2}{*}{ sea } & $\mathrm{F}$ & TGCCGATCAATTTATGGCTAGA & 62 & \multirow{2}{*}{207} & \multirow[t]{2}{*}{ This study } \\
\hline & $\mathrm{R}$ & CCGAAGGTTCTGTAGAAGTATGAA & & & \\
\hline \multirow{2}{*}{ seb } & $\mathrm{F}$ & GGACACTAAGTTAGGGAATTATGA & 60 & \multirow{2}{*}{200} & \multirow[t]{2}{*}{ This study } \\
\hline & $\mathrm{R}$ & GCTCAGTTACACCACCATAC & & & \\
\hline \multirow{2}{*}{ sec } & $\mathrm{F}$ & GGTATGATATGATGCCTGCAC & 61 & \multirow{2}{*}{111} & \multirow[t]{2}{*}{ This study } \\
\hline & $\mathrm{R}$ & GGTGGACTTCTATCTTCACACT & & & \\
\hline \multirow{2}{*}{ see } & $\mathrm{F}$ & GATCTTCAGGCAAGGCATTATT & 61 & \multirow{2}{*}{122} & \multirow[t]{2}{*}{ This study } \\
\hline & $\mathrm{R}$ & TAACTTACCGTGGACCCTTC & & & \\
\hline \multirow{2}{*}{$\operatorname{seg}$} & $\mathrm{F}$ & TGTATGGTGGTGTAACTGAGCA & 64 & \multirow{2}{*}{272} & \multirow[t]{2}{*}{ This study } \\
\hline & $\mathrm{R}$ & TGGTGCAGGCATCATGTCATA & & & \\
\hline \multirow[t]{2}{*}{ nис } & $\mathrm{F}$ & GCGATTGATGGTGATACGGTI & 55 & \multirow{2}{*}{267} & \multirow[t]{2}{*}{ [21] } \\
\hline & $\mathrm{R}$ & AGCCAAGCCTTGACGAACTAAAGC & & & \\
\hline
\end{tabular}

F: forward; R: reverse; Temp: annealing temperature; bp: base pair. 


\subsection{Expression of SE Genes}

Isolated RNA was used for preparation of complementary DNA using Quanti-Tect Reverse Transcription kit (QIAGEN, Germany). RT-PCR was done using $5 \times$ FIREPol Eva Green, qPCR Mix, plus no ROX dye (Solis Bio-Dyne, Tartu, Estonia) using primers listed in Table 1.

RT-PCR was performed using a Rotor Gene Q thermocycler (QIAGEN, Hilden, Germany) programmed as follows: $95^{\circ} \mathrm{C}$ for $15 \mathrm{~min}$, followed by 35 cycles of denaturation at $95^{\circ} \mathrm{C}$ for $15 \mathrm{~s}$, annealing at temperatures specified for each primer as listed in Table 1 for $30 \mathrm{~s}$ and extension at $72^{\circ} \mathrm{C}$ for $1 \mathrm{~min}$. Expression of the target genes was normalized to the expression of reference gene (nuc) encoding nuclease enzyme. The gene expression level in samples was calculated relative to the housekeeping gene (endogenous reference gene) using a calibrator sample by the comparative ( $\Delta \Delta \mathrm{ct})$ method [23]. All measurements were performed in triplicate.

\subsection{Statistical Analysis}

Correlations between data were statistically analyzed using the Graphpad Instat 3. Fisher's exact test was used to evaluate these correlations where $\mathrm{P}$ value $<0.05$ was considered statistically significant.

\section{Results}

\subsection{Bacterial Isolates}

A total of 250 samples were collected from different hospitals. One hundred were identified as S. aureus. These isolates were obtained from various sources ( 93 clinical isolates and 7 environmental isolates).

Clinical sources included diabetic foot cases (D.F, 19 isolates), wound (W, 19 isolates), blood (Bl, 12 isolates), urine (U, 11 isolates), abscess (A, 9 isolates), burn (B, 10 isolates), sputum (Sp, 8 isolates) and throat swab (T.S, 5 isolates), where environmental (En, 7 isolates) were collected from hospital walls and floors to detect any abnormal increase in level of antimicrobial resistance or toxin prevalence in these hospitals environments.

\subsection{Antimicrobial Susceptibility Testing}

As determined by disc-diffusion antimicrobial susceptibility testing, all isolates showed resistance to at least one antimicrobial agent. A high resistance percentage was observed for ceftazidime (100\%), cefoxitin (88\%) and amoxicillin-clavulanic (77\%). A moderate activity was noticed for tobramycin, erythromycin, ampicillin-sulbactam, cefepime and oxacillin where (32\% - 47\%) of isolates were resistant. On the other hand a lower resistance was observed for imipenem, ciprofloxacin, cephalothin and amikacin (Figure 1).

Among isolates, 88 were identified as methicillin resistant Staph. aureus (MRSA) where they showed resistance to cefoxitin. In addition, 33 were considered multidrug-resistant (MDR) (resistant to at least three different antimicrobial classes).

\subsection{Polymerase Chain Reaction (PCR)}

PCR analysis of the five toxin genes revealed that $88 \%$ of isolates harbored one or more of the tested

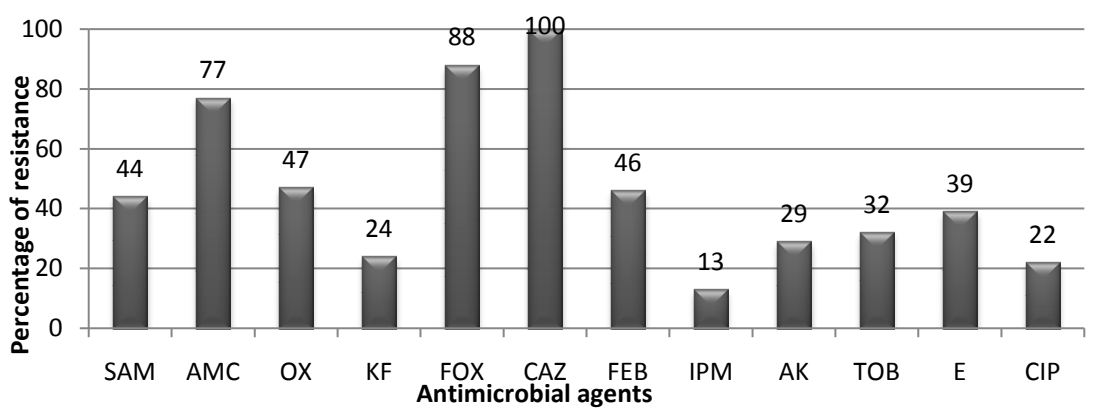

Figure 1. Percentage of resistant isolates to each antimicrobial agent. SAM: ampicillin- sulbactam, AMC: amoxicillin-clavulanic acid, OX: oxacillin, KF: cephalothin, FOX: cefoxitin, CAZ: ceftazidime, FEB: cefepime, IPM: imipenem, AK: amikacin, TOB: tobramycin, E: erythromycin, CIP: ciprofloxacin. 
Table 2. Distribution of enterotoxin gene patterns among isolation sources and resistance categories of $S$. aureus isolates.

\begin{tabular}{|c|c|c|c|c|c|c|c|c|c|c|c|c|c|c|c|c|c|}
\hline \multirow{3}{*}{ 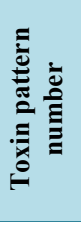 } & \multicolumn{5}{|c|}{ Pattern } & \multirow{3}{*}{ 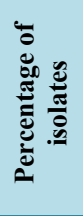 } & \multicolumn{2}{|c|}{$\begin{array}{l}\text { Resistance } \\
\text { category }\end{array}$} & \multicolumn{9}{|c|}{ Distribution among sources } \\
\hline & \multirow[t]{2}{*}{ sea } & \multirow[t]{2}{*}{ seb } & \multirow[t]{2}{*}{$\sec$} & \multirow[t]{2}{*}{ see } & \multirow[t]{2}{*}{ seg } & & \multirow{2}{*}{ 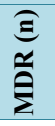 } & \multirow{2}{*}{$\sum_{\bar{z}}^{\frac{\alpha}{\hat{~}}}$} & \multicolumn{8}{|c|}{ Clinical } & \multirow{2}{*}{$\begin{array}{c}\begin{array}{c}\text { Non } \\
\text { clinica }\end{array} \\
\text { En } \\
\end{array}$} \\
\hline & & & & & & & & & D.F & W & BI & $\mathbf{U}$ & B & $\mathbf{A}$ & Sp & T.S & \\
\hline $\mathrm{T} 1$ & + & & & & & $25 \%$ & 7 & 18 & 3 & 5 & 7 & 2 & 1 & 3 & 3 & 1 & $\mathbf{0}$ \\
\hline $\mathrm{T} 2$ & & + & & & & $9 \%$ & 2 & 7 & 1 & 3 & $\mathbf{0}$ & 1 & $\mathbf{0}$ & 1 & $\mathbf{0}$ & $\mathbf{0}$ & 3 \\
\hline $\mathrm{T} 3$ & & & + & & & $2 \%$ & 1 & 1 & 1 & $\mathbf{0}$ & $\mathbf{0}$ & $\mathbf{0}$ & 1 & $\mathbf{0}$ & $\mathbf{0}$ & $\mathbf{0}$ & $\mathbf{0}$ \\
\hline $\mathrm{T} 4$ & & & & + & & $3 \%$ & 1 & 2 & $\mathbf{0}$ & 1 & 1 & 1 & $\mathbf{0}$ & $\mathbf{0}$ & $\mathbf{0}$ & 0 & 0 \\
\hline T5 & + & + & & & & $11 \%$ & 7 & 4 & 3 & 3 & $\mathbf{0}$ & 1 & 3 & 1 & $\mathbf{0}$ & 0 & 0 \\
\hline T6 & + & & + & & & $10 \%$ & 4 & 6 & 4 & 3 & $\mathbf{0}$ & $\mathbf{0}$ & 1 & $\mathbf{0}$ & 2 & 0 & 0 \\
\hline $\mathrm{T} 7$ & + & & & + & & $9 \%$ & 3 & 6 & 0 & 1 & 3 & 2 & 2 & $\mathbf{0}$ & 1 & 0 & 0 \\
\hline $\mathrm{T} 8$ & & + & + & & & $2 \%$ & $\mathbf{0}$ & 2 & 0 & 0 & $\mathbf{0}$ & 1 & $\mathbf{0}$ & 1 & 0 & 0 & 0 \\
\hline T9 & & + & & + & & $4 \%$ & 1 & 3 & 0 & 1 & 1 & $\mathbf{0}$ & $\mathbf{0}$ & 1 & 1 & 0 & 0 \\
\hline $\mathrm{T} 10$ & & + & & & + & $2 \%$ & 1 & 1 & 0 & 0 & $\mathbf{0}$ & $\mathbf{0}$ & $\mathbf{0}$ & $\mathbf{0}$ & 0 & 1 & 1 \\
\hline $\mathrm{T} 11$ & + & + & + & & & $5 \%$ & 1 & 4 & 4 & 0 & $\mathbf{0}$ & 1 & $\mathbf{0}$ & $\mathbf{0}$ & 0 & 0 & 0 \\
\hline $\mathrm{T} 12$ & + & + & & + & & $1 \%$ & $\mathbf{0}$ & 1 & 0 & 1 & $\mathbf{0}$ & $\mathbf{0}$ & $\mathbf{0}$ & $\mathbf{0}$ & 0 & 0 & 0 \\
\hline $\mathrm{T} 13$ & + & + & & & + & $1 \%$ & $\mathbf{0}$ & 1 & 0 & 0 & 0 & $\mathbf{0}$ & $\mathbf{0}$ & $\mathbf{0}$ & 0 & 0 & 1 \\
\hline $\mathrm{T} 14$ & + & & + & + & & $1 \%$ & 1 & 0 & 0 & 0 & 0 & $\mathbf{0}$ & $\mathbf{0}$ & 1 & 0 & 0 & 0 \\
\hline $\mathrm{T} 15$ & + & + & + & & + & $2 \%$ & $\mathbf{0}$ & 2 & 0 & 0 & 0 & $\mathbf{0}$ & $\mathbf{0}$ & 1 & 0 & 1 & $\mathbf{0}$ \\
\hline $\mathrm{T} 16$ & + & + & + & + & & $1 \%$ & 1 & 0 & 0 & 0 & 0 & $\mathbf{0}$ & 1 & $\mathbf{0}$ & 0 & 0 & 0 \\
\hline $\mathrm{T} 17$ & & & & & & $12 \%$ & 3 & 9 & 3 & 1 & 0 & 2 & 1 & $\mathbf{0}$ & 1 & 2 & 2 \\
\hline
\end{tabular}

D.F: Diabetic foot, W: Wound, Bl: Blood, U: Urine, B: Burn, A: Abscess, Sp: Sputum, T.S: Throat swab, En: Environmental, MDR: Multidrug-resistant, NMDR: Non-multidrug-resistant, $\mathbf{n}$ : number of isolates.

staphylococcal enterotoxin genes. The most frequent gene was sea (66\% of isolates), followed by seb (38\%), sec $(23 \%)$, see $(19 \%)$ and $\operatorname{seg}(5 \%)$.

The tested S. aureus isolates were distributed into 17 different patterns (T1-T17) according to Table 2. The most predominant pattern was $\mathrm{T} 1$ involving 25 isolates harboring sea gene only. The second most common pattern was T5 representing 11 isolates harboring both sea and seb genes. However, patterns T12, T13, T14 and T16 were the least common, where only one isolate represented each pattern.

In addition, $39 \%$ of isolates harbored only one toxin gene (sea, seb, sec, see), while $49 \%$ carried toxin gene combinations (38\% harbored 2 genes, $8 \%$ harbored 3 genes and only $3 \%$ harbored 4 genes.

Among the 88 MRSA isolates, 76 harbored at least one enterotoxin gene and among them 56 isolates harbored the sea gene, 33 harbored seb gene, 17 harbored sec, 17 harbored see gene and seg gene was harbored by 4 isolates. The most common enterotoxin pattern in the MRSA toxigenic isolates was T1 coding for sea gene only (21 isolates) followed by T5 coding for sea and seb gene combination (11 isolates).

\subsection{Real-Time PCR Analysis of $S$, aureus Enterotoxins}

In order to study the relative expression of the tested genes, RNA was isolated from the selected $20 \mathrm{~S}$. aureus isolates. The isolated RNA had an A260/A280 ratio that ranged between 1.766 and 2.12, while the concentation range was $(0.352-12.95) \mu \mathrm{g} / \mu \mathrm{l}$. From each isolate $1 \mu \mathrm{g}$ of RNA was used in c-DNA synthesis. The standard curve of the housekeeping gene $n u c$ and of all expressed enterotoxins genes showed $\mathrm{R}^{2}$ values of $0.97-0.99$. They showed the same melting profile and formation of pure amplicons indicated the specificity of the assay. The relative expression levels of SE were analyzed using the comparative method $\left(2^{-\Delta \Delta \mathrm{Ct}}\right)$ method.

Among the tested twenty isolates, 20 harbored sea gene, 12 harbored seb gene, 12 harbored sec gene, 7 har- 
bored see gene and 3 harbored seg gene as detected by PCR.

Sea gene expression was observed in all of the 20 isolates by variable degrees (Figure 2). Regarding seb gene, it was expressed in 11 out of 12 isolates (Figure 3). In contrast, sec and see genes were not expressed in any of the tested isolates, while the new (non-classical) enterotoxin gene (seg) was expressed in the 3 harboring isolates (Figure 4).

It was found that $70 \%$ of MDR isolates of the tested isolates expressed sea gene with high degree ( $\mathrm{P}$ value $=$ 0.0031) (Figure 2), seb and seg genes were highly expressed in 2 isolates that were non-multidrug-resistant (NMDR) and showed low sea gene expression (Figure 3, Figure 4) but no significant association was found.

\section{Discussion}

S. aureus is a major human pathogen found in hospitals and the community [24]. This bacterium is an opportunistic pathogen that can result in a variety of self-limiting and also life-threatening diseases in humans [25].

The clinical importance of $S$. aureus is attributed to remarkable virulence factors, toxins and enzymes, surface proteins, as well as the rapid development of antimicrobial agents resistance [26]. Among the most associated virulence factors with this bacterium, are the heat-stable staphylococcal enterotoxins (SEs) [27]. These toxins are the causative agents of staphylococcal food poisoning syndrome in man and they may be involved in other types of infections [28].

Emergence of antibiotic resistant strains of $S$. aureus is a major public health problem since the bacteria can be easily spread in the environment. During the last two decades, the rate of infections caused by methicillin-resistant Staphylococcus aureus (MRSA) has been notably increased world-wide [29]. Multidrug-resistant $S$. aureus have been frequently isolated from different origins, including food, water, human nasal mucosa and clinical cases [30]. Accordingly, it was extremely important in this study to detect the enterotoxigenicity as well as the antimicrobial susceptibility of $S$. aureus isolates belonging to various sources and try to find correlations between different variables.

In the present study, $100 \mathrm{~S}$. aureus isolates were investigated for susceptibility against 12 antimicrobial agents belonging to four different classes (Figure 1). All of the isolates were resistant to ceftazidime. Also, 77\% of isolates were resistant to amoxicillin/clavulanic acid. In a study of Manoharan et al. 2008, the percentage of resistance to this combination was $84.38 \%$ of isolates. These high levels of resistance may be attributed to misuse of antibiotics [31].

Intermediate frequencies of resistance towards oxacillin, cefepime, ampicillin/sulbactam, erythromycin and tobramycin antibiotics $(47 \%, 46 \%, 44 \%, 39 \%$ and $32 \%$ respectively) were recorded. The level of oxacillin resistance (47\%) was higher than those reported by Sina et al. 2013 and Tokajian et al. 2011 (32\%, 25\%) respectively [32] [33]. Perveen et al. 2013 demonstrated that $12 \%$ of isolates were resistant to cefepime [34] which come in contrast with our finding. Opere et al. 2013 reported that erythromycin level of resistance was $32 \%$, which was consistent with our results [35]. Resistance towards tobramycin in this study was coherent with Schmitz et al. 1999 who demonstrated that 29\% of S. aureus isolates were resistant to tobramycin [36], while Elazhari et al. 2011 showed that only 1.43\% of isolates were resistant [37].

For ciprofloxacin, 22\% of isolates are resistant antimicrobial agent, Shittu and Lin, 2006 showed a lower level of resistance to ciprofloxacin $(<10 \%)$ [38], while Opere et al. 2013 showed higher level of ciprofloxacin resistance (39\%) [35].

The majority of our isolates were susceptible to amikacin and cephalothin $(71 \%, 76 \%)$ respectively. This was also reported by Hauschild et al. 2008, Gade and Qazi, 2014 who demonstrated that $75.6 \%$ and $74 \%$ of $S$. aureus isolates were susceptible to amikacin respectively [39] [40]. Since cephalothin is a first generation cephalosporin so, it has good activity against $S$. aureus infections [41]. Imipenem antibiotic showed the highest activity towards isolates, where $87 \%$ of them were susceptible. This result was in accordance with the study of Asadollahi et al. 2014, in which $98 \%$ of isolates were susceptible [42].

In this study, $88 \%$ of isolates were identified as MRSA depending on cefoxitin $(30 \mu \mathrm{g})$ disk diffusion results [19]. Methicillin resistance was detected in S. aureus using cefoxitin with $100 \%$ specificity and sensitivity [43]. Also Alfatemi et al. 2014 demonstrated that cefoxitin had 100\% sensitivity and 99\% specificity for MRSA detection [20]. Our findings agree with the study of Yaseen et al. 2013, who reported that (88\%) of isolates were MRSA [44]. Multidrug-resistance (MDR) was defined as resistance to at least 3 antimicrobial classes [45] [46]. $33 \%$ of our isolates were MDR, Seas et al. 2006 demonstrated a lower percentage, where $25 \%$ of isolates were MDR [45]. 


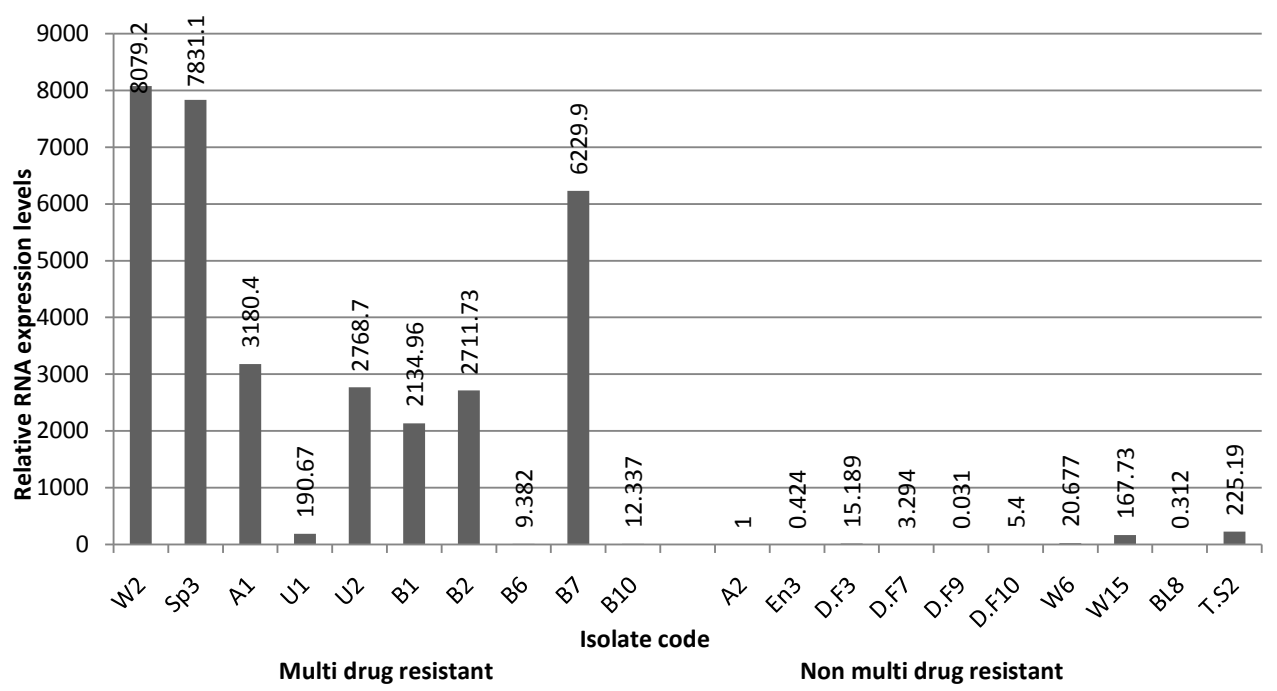

Figure 2. Relative sea gene expression levels in 20 isolates calculated by the comparative method $(\Delta \Delta \mathrm{ct})$ method.

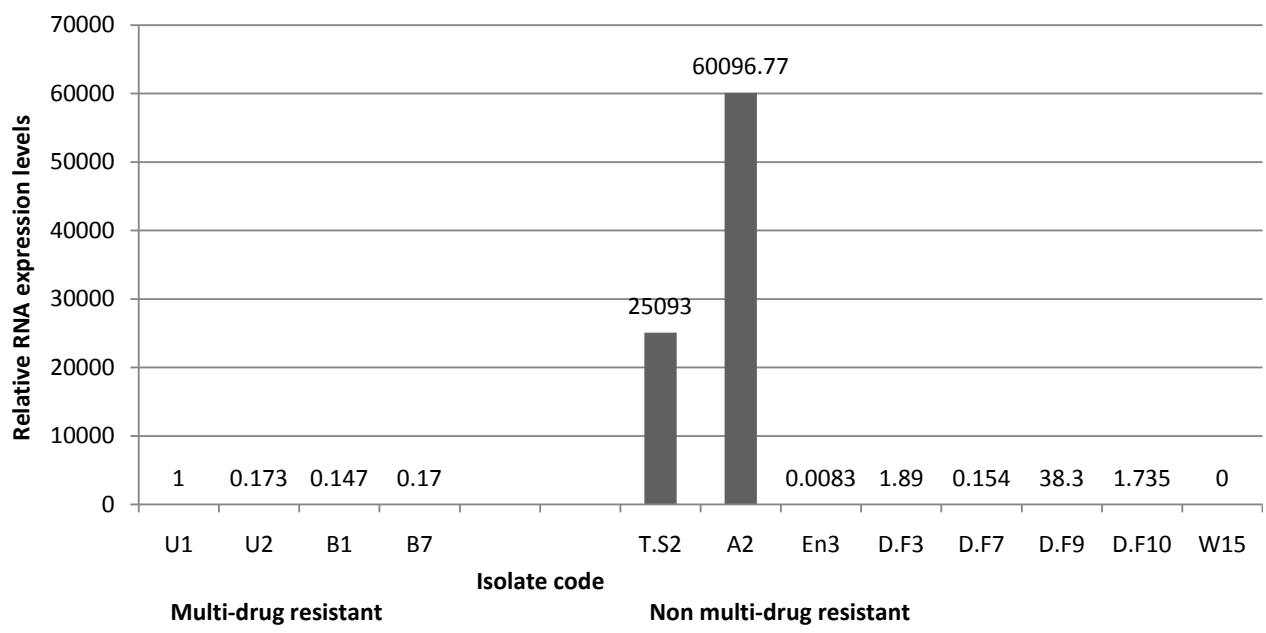

Figure 3. Relative $s e b$ gene expression levels in 12 isolates calculated by the comparative method $(\Delta \Delta \mathrm{ct})$ method.

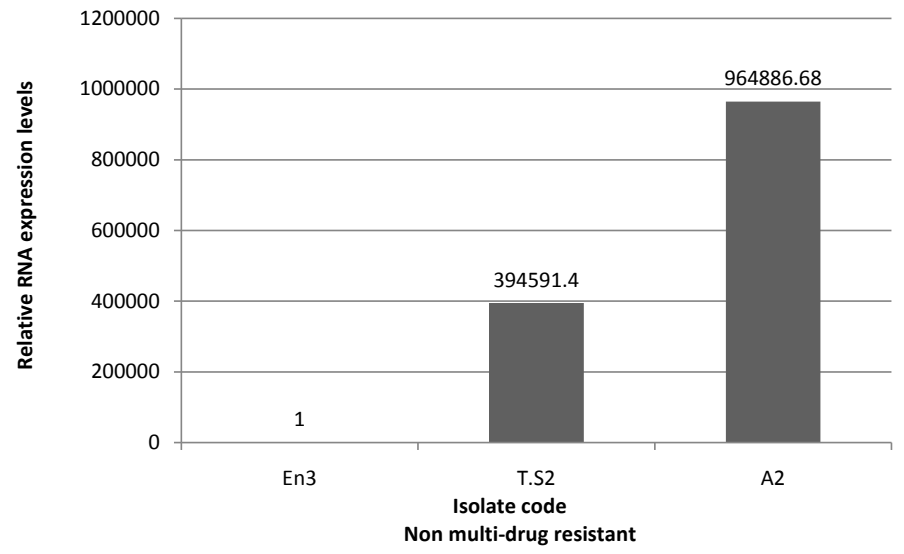

Figure 4. The relative seg gene expression levels in 3 isolates calculated by the comparative method $(\Delta \Delta \mathrm{ct})$ method. 
The prevalence of five SEs encoding genes was investigated by PCR amplification. $88 \%$ of isolates harbored one or more enterotoxin genes. This result was to some extent in accordance with the studies of Elazhari et al. 2011 and Cao et al. 2012 who found toxigenicity levels of (76.4\% and 93.5\%) respectively [37] [47], however, Becker et al. 2003 and Naffa et al. 2006, reported a lower level of toxigenicity 43\% and 23\%, respectively [48] [49].

Among 88 SE genes positive isolates, only 16 different toxin patterns were detected (Table 2); this can be explained by the horizontal-gene transfer among strains [50]. Since all SE genes are carried on accessory genetic elements, including plasmids, genomic island vSa, S. aureus pathogenicity islands (SaPIs) and prophages, or next to the staphylococcal cassette chromosome (SCC) elements. Most of these are mobile genetic elements, which enable them to spread among $S$. aureus isolates increasing their ability to cause disease and contribute to the emergence of pathogenic strains [51].

The sea gene was the most predominant toxin gene detected in $66 \%$ of isolates, this high percentage is in the line with other studies who reported sea gene prevalence rate of 55.1\%, 65.22\%, 60.6\% [52]-[54]. However, a much lower frequency of sea gene was reported by other studies where sea gene prevalence was $25 \%$ and $18.86 \%$ [33] [55]. The second most prevalent toxin gene detected in this study was seb, where (38\%) of isolates harbored this gene, this was in accordance with the study performed by Sina et al. 2013 who reported that $44.3 \%$ of isolates were seb gene carriers [32]. It was found that only one isolate (8\%) out of twelve isolates from blood carried the seb gene, similarly only $5 \%$ of $S$. aureus isolates collected from blood stream infections harbored this gene [56].

Regarding the sec gene, it was detected in $23 \%$ of isolates. This was in accordance with the results of Lim et $a l, 2012$ who reported that the prevalence rate of sec gene was 19\% [57]. However, higher prevalence rates for sec gene (61.3\% and 41.5\%) were reported [47] [55]. For see gene, only 19\% of isolates harbored it. Likewise, see gene was harbored by 15.09\% [55]. However, Asadollahi et al. 2014 reported a higher level of see gene $(31 \%)$ [42]. In contrast, other studies did not detect see gene in any of the isolates [33] [47] [53].

The prevalence of the non-classical (recently described) enterotoxin G encoding gene (seg) was also studied; it was the least prevalent gene in our study, where it was harbored by only 5\% of isolates. Among S. aureus isolates collected from pediatric patients in Iran [55], none of the isolates carried the seg gene. However, a higher level of seg gene was recorded in other studies, where the prevalence rate of this gene was $25 \%$ and $32.6 \%$ [33] [53]. The coexistence of two or more toxins was observed with a prevalence of $49 \%$, higher combination rates $(67.2 \%, 76.9 \%, 94.57 \%)$ were found in previous studies [47] [53] [58].

The tested $S$. aureus isolates were distributed into 17 different patterns (T1-T17) according to their toxins. Patterns T1:T4 represents only a single gene, patterns (T5:T16) represent two or more toxin genes. Pattern 17 was for isolates devoid from toxin genes. The most common combinations in this study were (sea and seb) represented by pattern T5 (11\%), followed by pattern T6 (sea and sec) genes (10\%) and pattern T7 (sea and see) $(9 \%)$. In a study of Kamarehei et al. 2013, 18.8\% of isolates combined sea and seb genes [54]. Our data show that the coexistence of three toxin genes was found only in 8 isolates. A lower frequency (3\%) was noticed for isolates harboring four toxin genes. However, some of our findings differed from those reported in other countries. In a study carried out in the Bronx, New York up to 12 SE genes were detected per a given S. aureus strain [59]. In our study, we did not observe any isolate harbored more than 4 enterotoxin genes.

Variations in enterotoxin encoding genes prevalence among studies may be attributed to differences in many factors, including the origin of the isolates (food, clinical or environmental samples), study locations, levels of hygiene restrictions among countries and also assay methods.

One of the most important finding in our study is that no statistically significant association between prevalence of toxin genes ( $\mathrm{seb}$, sec and see) and isolates sources, except for sea gene, which was significantly associated with clinical isolates $(\mathrm{P}$ value $=0.0059)$, where the environmental isolates did not show a remarkable increase in the toxin gene prevalence.

The relationship between virulence and resistance remains unclear. Some studies suggested a negative correlation between methicillin resistance and virulence, as resistance to antibiotics is associated with loss of pathogenic fitness and decreased virulence potential [60] [61]. Others observed that, in general, there were no differences between MRSA and MSSA in SEs levels [62]. In agreement with the study of Indrawattana et al. 2013 who found that sec gene was more associated with MSSA [53]. Our study confirmed that sec gene was significantly associated with isolates susceptible to cefoxitin (MSSA) (P value $=0.0281$ ). Moreover, sea gene was more prevalent in isolates resistant to imipenem and ciprofloxacin antimicrobials with ( $\mathrm{P}$ value $=0.0038$ and 
0.0237), respectively which was in accordance with Pourmand et al. 2009 who found a significant association between sea gene prevalence and resistance to a number of antimicrobial agents including ciprofloxacin [63].

It is well known that detection of toxin genes, does not necessarily mean the ability of toxin production [58], this may be due to mutation in the gene regulatory region [64], so it was important for us to demonstrate the ability to express the studied enterotoxin genes among selected 20 isolates by real-time PCR technique. Sea gene was expressed in all the tested 20 isolates by variable degrees (Figure 2). In addition, seb gene was expressed in 11 out of 12 isolates that harbored this gene. However, only two of these eleven isolates showed relatively very high expression levels (Figure 3). For seg gene, it was expressed in all of the 3 tested isolates with two of them showing very high relative expression levels (Figure 4). Regarding sec and see genes, they were not expressed in any of the isolates tested by RT-PCR. The same results were obtained by Vasconcelos et al. 2011, where no expression of see gene was observed for any isolate [65]. Also, our finding was in agreement with Zigo et al. 2014, where sec gene was not produced in any of the tested isolates [28].

Analysis of toxin pattern distribution among multidrug-resistant and non multidrug-resistant isolates did not allow the determination of a clear correlation between the determined toxin pattern distribution among MDR and NMDR. This is because $64.7 \%$ of patterns were shared by both MDR and NMDR. Our results were consistent with Indrawattana et al. 2013 who reported that no data was available in the literature correlating the ability to produce toxins in S. aureus and antibiograms [53]. However, an interesting correlation was found between high sea gene expression and multi-drug resistance $(\mathrm{MDR})(\mathrm{P}$ value $=0.0031)$. In addition, the 2 isolates that showed high seb gene expression as well as high seg gene expression were NMDR strains, but no significant correlation was found.

\section{Conclusion}

The present study highlights the high prevalence of enterotoxin genes, especially sea gene. The enterotoxin genes (seb, sec and see) were demonstrated to be strain dependent and not associated with the isolation source. However, sea gene was significantly associated with clinical isolates. Since detection of toxin genes does not necessarily mean the ability of toxin production, our results suggest that measurement of expression level of those toxins at the transcript level is necessary to evaluate the potential of $S$. aureus to cause severe disease. Although the genetic association between resistance and enterotoxins is poorly understood, evidence in our study indicates that there is a significant correlation between sea gene and both imipenem and ciprofloxacin resistance. Moreover, sec gene was significantly associated with MSSA isolates. An interesting correlation was also found between high sea gene expression and multidrug-resistance. Although isolates collected from hospitals environment did not show the expected antimicrobial resistance and toxin prevalence, more governed health restrictions are still needed to control the spread of S. aureus infections in our hospitals environment. Since these isolates may provide a source of fomite transmission, which may be associated with a high degree of antibiotic resistance and virulence.

\section{Acknowledgements}

All appreciation to Mansoura University hospitals staff members and patients for providing isolates used in the study. Many thanks for workers in Seeds Unit faculty of agriculture, Mansoura University.

\section{Conflict of Interests}

The authors declare that they have no competing interests.

\section{Authors' Contributions}

Shaymaa H. Abdel-Rhman, Rasha Barwa and Mohammed A. El-Sokkary conceived and designed the experiments; Enas Y. Mohammed performed the experiments; Shaymaa H. Abdel-Rhman, Rasha Barwa and Enas Y. Mohammed analyzed the data; Shaymaa H. Abdel-Rhman, Rasha Barwa and Enas Y. Mohammed contributed reagents/materials/analysis tools; all authors wrote the paper, read and approved the final manuscript.

\section{Authors' Information}

Microbiology and Immunology Department, Faculty of Pharmacy, Mansoura University, Mansoura 35516, Egypt. 


\section{References}

[1] Harris, L.G., Foster, S.J. and Richards, R.G. (2002) An Introduction to Staphylococcus aureus, and Techniques for Identifying and Quantifying S. aureus Adhesins in Relation to Adhesion to Biomaterials: Review. European Cells and Materials Journal, 4, 39-60.

[2] Plata, K., Rosato, A.E. and Wegrzyn, G. (2009) Staphylococcus aureus as an Infectious Agent: Overview of Biochemistry and Molecular Genetics of Its Pathogenicity. Acta Biochimica Polonica, 56, 597-612.

[3] Heyman, D.L. (2004) Control of Communocable Diseases Manual. American Public Health Association, Washington DC.

[4] Ortega, E., Abriouel, H., Lucas, R. and Galvez, A. (2010) Multiple Roles of Staphylococcus aureus Enterotoxins: Pathogenicity, Superantigenic Activity, and Correlation to Antibiotic Resistance. Toxins (Basel), 2, 2117-2131. http://dx.doi.org/10.3390/toxins2082117

[5] El-Jakee, J., Nagwa, A.S., Bakry, M., Zouelfakar, S.A., Elgabry, E. and El-Said, W.G. (2008) Characteristics of Staphylococcus aureus Strains Isolated from Human and Animal Sources. American-Eurasian Journal of Agricultural \& Environmental Sciences, 4, 221-229.

[6] Jackranukul, C., Panvisavas, N. and Chaturongakul, S. (2013) Detection of Staphylococcus aureus Enterotoxin Type I Using qPCR. Chiang Mai Journal of Science, 40, 143-150.

[7] Jorgensen, H.J., Mork, T., Hogasen, H.R. and Rorvik, L.M. (2005) Enterotoxigenic Staphylococcus aureus in Bulk Milk in Norway. Journal of Applied Microbiology, 99, 158-166. http://dx.doi.org/10.1111/j.1365-2672.2005.02569.x

[8] Nema, V., Agrawal, R., Kamboj, D.V., Goel, A.K. and Singh, L. (2007) Isolation and Characterization of Heat Resistant Enterotoxigenic Staphylococcus aureus from a Food Poisoning Outbreak in Indian Subcontinent. International Journal of Food Microbiology, 117, 29-35. http://dx.doi.org/10.1016/j.ijfoodmicro.2007.01.015

[9] Principato, M. and Qian, B.F. (2014) Staphylococcal Enterotoxins in the Etiopathogenesis of Mucosal Autoimmunity within the Gastrointestinal Tract. Toxins (Basel), 6, 1471-1489. http://dx.doi.org/10.3390/toxins6051471

[10] Balaban, N. and Rasooly, A. (2000) Staphylococcal Enterotoxins. International Journal of Food Microbiology, 61, 110. http://dx.doi.org/10.1016/S0168-1605(00)00377-9

[11] Omoe, K., Hu, D.-L., Ono, H.K., Shimizu, S., Takahashi-Omoe, H., Nakane, A., Uchiyama, T., Shinagawa, K. and Imanishi, K. (2013) Emetic Potentials of Newly Identified Staphylococcal Enterotoxin-Like Toxins. Infection and Immunity, 81, 3627-3631. http://dx.doi.org/10.1128/IAI.00550-13

[12] Ono, H.K., Sato'o, Y., Narita, K., Naito, I., Hirose, S., Hisatsune, J., Asano, K., Hu, D.L., Omoe, K., Sugai, M. and Nakane, A. (2015) Identification and Characterization of a Novel Staphylococcal Emetic Toxin. Applied and Environmental Microbiology, 81, 7034-7040. http://dx.doi.org/10.1128/AEM.01873-15

[13] Fernandez, M.M., De Marzi, M.C., Berguer, P., Burzyn, D., Langley, R.J., Piazzon, I., Mariuzza, R.A. and Malchiodi, E.L. (2006) Binding of Natural Variants of Staphylococcal Superantigens SEG and SEI to TCR and MHC Class II Molecule. Molecular Immunology, 43, 927-938. http://dx.doi.org/10.1016/j.molimm.2005.06.029

[14] Pinchuk, I.V., Beswick, E.J. and Reyes, V.E. (2010) Staphylococcal Enterotoxins. Toxins (Basel), 2, $2177-2197$. http://dx.doi.org/10.3390/toxins2082177

[15] Munson, S.H., Tremaine, M.T., Betley, M.J. and Welch, R.A. (1998) Identification and Characterization of Staphylococcal Enterotoxin Types G and I from Staphylococcus aureus. Infection and Immunity, 66, 3337-3348.

[16] Blaiotta, G., Ercolini, D., Pennacchia, C., Fusco, V., Casaburi, A., Pepe, O. and Villani, F. (2004) PCR Detection of Staphylococcal Enterotoxin Genes in Staphylococcus spp. Strains Isolated from Meat and Dairy Products. Evidence for New Variants of seG and seI in S. aureus AB-8802. Journal of Applied Microbiology, 97, 719-730. http://dx.doi.org/10.1111/j.1365-2672.2004.02349.x

[17] Chiang, Y.C., Liao, W.W., Fan, C.M., Pai, W.Y., Chiou, C.S. and Tsen, H.Y. (2008) PCR Detection of Staphylococcal Enterotoxins (SEs) N, O, P, Q, R, U, and Survey of SE Types in Staphylococcus aureus Isolates from Food-Poisoning Cases in Taiwan. International Journal of Food Microbiology, 121, 66-73. http://dx.doi.org/10.1016/j.ijfoodmicro.2007.10.005

[18] Collee, J.G., Miles, R.S. and Watt, B. (1996) Tests for the Identification of Bacteria. Mackie and Macartney Practical Medical Microbiology, Churchill Livingstone, New York, 413-424.

[19] Clinical and Laboratory Standards Institute (2011) Performance Standards for Antimicrobial Susceptibility Testing; Twenty-First Informational Supplement. M100-S21. Clinical and Laboratory Standards Institute, Wayne.

[20] Alfatemi, S.M., Motamedifar, M., Hadi, N. and Saraie, H.S. (2014) Analysis of Virulence Genes among Methicillin Resistant Staphylococcus aureus (MRSA) Strains. Jundishapur Journal of Microbiology, 7, e10741.

[21] Brakstad, O.G., Aasbakk, K. and Maeland, J.A. (1992) Detection of Staphylococcus aureus by Polymerase Chain 
Reaction Amplification of the nuc Gene. Journal of Clinical Microbiology, 30, 1654-1660.

[22] Abdel-Rhman, S.H. (2016) Evaluation of Total RNA Isolation Methods from Staphylococcus aureus. New Egyptian Journal of Microbiology, 43, 50-57.

[23] Schmittgen, T.D. and Livak, K.J. (2008) Analyzing Real-Time PCR Data by the Comparative $\mathrm{C}_{\mathrm{T}}$ Method. Nature Protocols, 3, 1101-1108. http://dx.doi.org/10.1038/nprot.2008.73

[24] Verkaik, N.J., Dauwalder, O., Antri, K., Boubekri, I., de Vogel, C.P., Badiou, C., Bes, M., Vandenesch, F., Tazir, M., Hooijkaas, H., Verbrugh, H.A., van Belkum, A., Etienne, J., Lina, G., Ramdani-Bouguessa, N. and van Wamel, W.J. (2010) Immunogenicity of Toxins during Staphylococcus aureus Infection. Clinical Infectious Diseases, 50, 61-68. http://dx.doi.org/10.1086/648673

[25] Murray, P.R., Baron, E.J., Jorgenson, J.H., Landry, M.L., Pfaller, M.A. and Yolken, R.H. (2003) Manual of Clinical Microbiology. American Society of Microbiology Press, Washington DC.

[26] Arvidson, S. and Tegmark, K. (2001) Regulation of Virulence Determinants in Staphylococcus aureus. International Journal of Medical Microbiology, 291, 159-170. http://dx.doi.org/10.1078/1438-4221-00112

[27] Sabouni, F., Mahmoudi, S., Bahador, A., Pourakbari, B., Sadeghi, R.H., Ashtiani, M.T., Nikmanesh, B. and Mamishi, S. (2014) Virulence Factors of Staphylococcus aureus Isolates in an Iranian Referral Children's hospital. Osong Public Health and Research Perspectives, 5, 96-100. http://dx.doi.org/10.1016/j.phrp.2014.03.002

[28] Zigo, F., Vasi, M., Elecko, J., Farkašová, Z. and Chripková, M. (2014) Antibiotic Resistance and Production of Enterotoxins of Staphylococcus spp. Isolated from Samples of Milk in Dairy Sheep. International Journal of Latest Research in Science and Technology, 3, 99-102.

[29] Ippolito, G., Leone, S., Lauria, F.N., Nicastri, E. and Wenzel, R.P. (2010) Methicillin-Resistant Staphylococcus aureus: The Superbug. International Journal of Infectious Diseases, 14, S7-S11. http://dx.doi.org/10.1016/j.ijid.2010.05.003

[30] Abulreesh, H.H. (2011) Multidrug-Resistant Staphylococci in the Environment. International Conference on Biotechnology and Environment Manual, 18, 1-6.

[31] Manoharan, M., Jayaraman, S., Illanchezian, S. and Jayasekar, J. (2008) Homologous Resistant Groups (HRGs) in Multidrug Resistant Staphylococcus aureus Isolated from Retail Foods in Vadapalani, Chennai. The Internet Journal of Microbiology, 7.

[32] Sina, H., Ahoyo, T.A., Moussaoui, W., Keller, D., Bankole, H.S., Barogui, Y., Stienstra, Y., Kotchoni, S.O., Prevost, G. and Baba-Moussa, L. (2013) Variability of Antibiotic Susceptibility and Toxin Production of Staphylococcus aureus Strains Isolated from Skin, Soft Tissue, and Bone Related Infections. BMC Microbiology, 13, 188. http://dx.doi.org/10.1186/1471-2180-13-188

[33] Tokajian, S., Haddad, D., Andraos, R., Hashwa, F. and Araj, G. (2011) Toxins and Antibiotic Resistance in Staphylococcus aureus Isolated from a Major Hospital in Lebanon. International Scholarly Research Network Microbiology, 2011, Article ID: 812049.

[34] Perveen, S., Naqvi, S.B. and Fatima, A. (2013) Antimicrobial Susceptibility Pattern of Clinical Isolates from Cases of Ear Infection Using Amoxicillin and Cefepime. SpringerPlus, 2, 288. http://dx.doi.org/10.1186/2193-1801-2-288

[35] Opere, B.O., Fashola, M.O., Adesida, S., Smith, S.I. and Adebiyi, O.A. (2013) Prevalence and Antibiotic Susceptibility Pattern of Staphylococcus aureus in Clinical Specimens. Advances in Life Science and Technology, 10, 1-5.

[36] Schmitz, F.J., Fluit, A.C., Gondolf, M., Beyrau, R., Lindenlauf, E., Verhoef, J., Heinz, H.P. and Jones, M.E. (1999) The Prevalence of Aminoglycoside Resistance and Corresponding Resistance Genes in Clinical Isolates of Staphylococci from 19 European Hospitals. The Journal of Antimicrobial Chemotherapy, 43, 253-259. http://dx.doi.org/10.1093/jac/43.2.253

[37] Elazhari, M., Elhabchi, D., Zerouali, K., Dersi, N., Elmalki, A., Hassar, M., Saile, R. and Timinouni, M. (2011) Prevalence and Distribution of Superantigen Toxin Genes in Clinical Community Isolates of Staphylococcus aureus. Journal of Bacteriology \& Parasitology, 2, 107. http://dx.doi.org/10.4172/2155-9597.1000107

[38] Shittu, A.O. and Lin, J. (2006) Antimicrobial Susceptibility Patterns and Characterization of Clinical Isolates of Staphylococcus aureus in KwaZulu-Natal Province, South Africa. BMC Infectious Diseases, 6, 125. http://dx.doi.org/10.1186/1471-2334-6-125

[39] Hauschild, T., Sacha, P., Wieczorek, P., Zalewska, M., Kaczynska, K. and Tryniszewska, E. (2008) Aminoglycosides Resistance in Clinical Isolates of Staphylococcus aureus from a University Hospital in Bialystok, Poland. Folia Histochemica et Cytobiologica, 46, 225-228. http://dx.doi.org/10.2478/v10042-008-0034-3

[40] Gade, N.D. and Qazi, M.S. (2014) Recent Trend of Aminoglycoside Resistance among Staphylococcus aureus Isolates in Tertiary Care Hospital. Journal of Microbiology and Antimicrobials, 6, 94-96. http://dx.doi.org/10.5897/JMA2014.0315

[41] Rayner, C. and Munckhof, W.J. (2005) Antibiotics Currently Used in the Treatment of Infections Caused by Staphylo- 
coccus aureus. Internal Medicine Journal, 35, S3-S16. http://dx.doi.org/10.1111/j.1444-0903.2005.00976.x

[42] Asadollahi, P., Delpisheh, A., Maleki, M.H., Jalilian, F.A., Alikhani, M.Y., Asadollahi, K., Soroush, S., Hematian, A., Emaneini, M. and Taherikalani, M. (2014) Enterotoxin and Exfoliative Toxin Gtenes among Methicillin-Resistant Staphylococcus aureus Isolates Recovered from Ilam, Iran. Avicenna Journal of Clinical Microbiology and Infection, $\mathbf{1}$ e20208. http://dx.doi.org/10.17795/ajcmi-20208

[43] Fernandes, C.J., Fernandes, L.A. and Collignon, P. (2005) Cefoxitin Resistance as a Surrogate Marker for the Detection of Methicillin-Resistant Staphylococcus aureus. The Journal of Antimicrobial Chemotherapy, 55, 506-510. http://dx.doi.org/10.1093/jac/dki052

[44] Yaseen, I.H., Shareef, A.Y. and Daoud, A.S. (2013) High Prevalence of Multidrug-Resistance MRSA and VRSA of Different Infections from Al-Jumhuory Teaching Hospital Patients in Mosul. Journal of Life Sciences, 7, 1255-1259.

[45] Seas, C., Hernandez, K., Ramos, R., Bazan, E., Rodriguez, I., Torres, A., Zamudio, C. and Gotuzzo, E. (2006) Oxacillin-Resistant and Multidrug-Resistant Staphylococcus aureus in Lima, Peru. Infection Control and Hospital Epidemiology, 27, 198-200. http://dx.doi.org/10.1086/500650

[46] Pillar, C.M., Draghi, D.C., Sheehan, D.J. and Sahm, D.F. (2008) Prevalence of Multidrug-Resistant, Methicillin-Resistant Staphylococcus aureus in the United States: Findings of the Stratified Analysis of the 2004 to 2005 Leader Surveillance Programs. Diagnostic Microbiology and Infectious Disease, 60, 221-224. http://dx.doi.org/10.1016/j.diagmicrobio.2007.08.007

[47] Cao, H., Wang, M., Zheng, R., Li, X., Wang, F., Jiang, Y. and Yang, Y. (2012) Investigation of Enterotoxin Gene in Clinical Isolates of Staphylococcus aureus. Journal of Southern Medical University, 32, 738-741.

[48] Becker, K., Friedrich, A.W., Lubritz, G., Weilert, M., Peters, G. and Von Eiff, C. (2003) Prevalence of Genes Encoding Pyrogenic Toxin Superantigens and Exfoliative Toxins among Strains of Staphylococcus aureus Isolated from Blood and Nasal Specimens. Journal of Clinical Microbiology, 41, 1434-1439. http://dx.doi.org/10.1128/JCM.41.4.1434-1439.2003

[49] Naffa, R.G., Bdour, S.M., Migdadi, H.M. and Shehabi, A.A. (2006) Enterotoxicity and Genetic Variation among Clinical Staphylococcus aureus Isolates in Jordan. Journal of Medical Microbiology, 55, 183-187. http://dx.doi.org/10.1099/jmm.0.46183-0

[50] Kelly, B.G., Vespermann, A. and Bolton, D.J. (2009) Horizontal Gene Transfer of Virulence Determinants in Selected Bacterial Foodborne Pathogens. Food and Chemical Toxicology, 47, 969-977. http://dx.doi.org/10.1016/j.fct.2008.02.007

[51] Argudin, M.A., Mendoza, M.C. and Rodicio, M.R. (2010) Food Poisoning and Staphylococcus aureus Enterotoxins. Toxins (Basel), 2, 1751-1773. http://dx.doi.org/10.3390/toxins2071751

[52] Bhatty, M., Ray, P., Singh, R., Jain, S. and Sharma, M. (2013) Presence of Virulence Determinants amongst Staphylococcus aureus Isolates from Nasal Colonization, Superficial \& Invasive Infections. The Indian Journal of Medical Research, 138, 143-146.

[53] Indrawattana, N., Sungkhachat, O., Sookrung, N., Chongsa-nguan, M., Tungtrongchitr, A., Voravuthikunchai, S.P., Kong-ngoen, T., Kurazono, H. and Chaicumpa, W. (2013) Staphylococcus aureus Clinical Isolates: Antibiotic Susceptibility, Molecular Characteristics, and Ability to form Biofilm. BioMed Research International, 2013, Article ID: 314654. http://dx.doi.org/10.1155/2013/314654

[54] Kamarehei, F., Ghaemi, E.A. and Dadgar, T. (2013) Prevalence of Enterotoxin A and B Genes in Staphylococcus aureus Isolated from Clinical Samples and Healthy Carriers in Gorgan City, North of Iran. Indian Journal of Pathology \& Microbiology, 56, 265-268. http://dx.doi.org/10.4103/0377-4929.120388

[55] Safaei, H.R., Pirasteh, H., Pournasiri, Z. and Dormanesh, B. (2015) Study the Enterotoxigenixity of Staphylococcus aureus Isolated from the Urine Samples of Pediatrics with UTIs. Biomedical and Pharmacology Journal, 8, 111-118. http://dx.doi.org/10.13005/bpj/566

[56] Wang, L.X., Hu, Z.D., Hu, Y.M., Tian, B., Li, J., Wang, F.X., Yang, H., Xu, H.R. and Li, Y.C. (2013) Molecular Analysis and Frequency of Staphylococcus aureus Virulence Genes Isolated from Bloodstream Infections in a Teaching Hospital in Tianjin, China. Genetics and Molecular Research, 12, 646-654. http://dx.doi.org/10.4238/2013.March.11.12

[57] Lim, K.T., Hanifah, Y.A., Mohd Yusof, M.Y. and Thong, K.L. (2012) Investigation of Toxin Genes among Methicillin-Resistant Staphylococcus aureus Strains Isolated from a Tertiary Hospital in Malaysia. Tropical Biomedicine, 29, 212-219.

[58] Adwan, G., Adwan, K., Jarrar, N., Salama, Y. and Barakat, A. (2013) Prevalence of seg, seh and sei Genes among Clinical and Nasal Staphylococcus aureus Isolates in Palestine. British Microbiology Research Journal, 3, 139-149. http://dx.doi.org/10.9734/BMRJ/2013/2913

[59] Varshney, A.K., Mediavilla, J.R., Robiou, N., Guh, A., Wang, X., Gialanella, P., Levi, M.H., Kreiswirth, B.N. and 
Fries, B.C. (2009) Diverse Enterotoxin Gene Profiles among Clonal Complexes of Staphylococcus aureus Isolates from the Bronx, New York. Applied and Environmental Microbiology, 75, 6839-6849. http://dx.doi.org/10.1128/AEM.00272-09

[60] Sapri, H.F., Sani, N.A.M., Neoh, H.-M. and Hussin, S. (2013) Epidemiological Study on Staphylococcus aureus Isolates Reveals Inverse Relationship between Antibiotic Resistance and Virulence Repertoire. Indian Journal of Microbiology, 53, 321-322. http://dx.doi.org/10.1007/s12088-013-0357-4

[61] Jimenez, J.N., Ocampo, A.M., Vanegas, J.M., Rodriguez, E.A., Garces, C.G., Patino, L.A., Ospina, S. and Correa, M.M. (2011) Characterisation of Virulence Genes in Methicillin Susceptible and Resistant Staphylococcus aureus Isolates from a Paediatric Population in a University Hospital of Medellin, Colombia. Memórias do Instituto Oswaldo Cruz, 106, 980-985. http://dx.doi.org/10.1590/S0074-02762011000800013

[62] Cameron, D.R., Howden, B.P. and Peleg, A.Y. (2011) The Interface between Antibiotic Resistance and Virulence in Staphylococcus aureus and Its Impact upon Clinical Outcomes. Clinical Infectious Diseases, 53, 576-582. http://dx.doi.org/10.1093/cid/cir473

[63] Pourmand, M.R., Memariani, M., Hoseini, M. and Yazdchi, S.B. (2009) High Prevalence of SEA Gene among Clinical Isolates of Staphylococcus aureus in Tehran. Acta Medica Iranica, 47, 357-361.

[64] Sharma, N.K., Rees, C.E. and Dodd, C.E. (2000) Development of a Single-Reaction Multiplex PCR Toxin Typing Assay for Staphylococcus aureus Strains. Applied and Environmental Microbiology, 66, 1347-1353. http://dx.doi.org/10.1128/AEM.66.4.1347-1353.2000

[65] Vasconcelos, N.G., Pereira, V.C., Araujo Jr., J.P. and da Cunha, M.L. (2011) Molecular Detection of Enterotoxins E, G, $\mathrm{H}$ and I in Staphylococcus aureus and Coagulase-Negative Staphylococci Isolated from Clinical Samples of Newborns in Brazil. Journal of Applied Microbiology, 111, 749-762. http://dx.doi.org/10.1111/j.1365-2672.2011.05076.x 